\title{
COVID-19-Shock:
}

\section{Considerations on Socio-Technological, Legal, Corporate, Economic and Governance Changes and Trends}

\author{
Julia M. Puaschunder, ${ }^{1,2}$ Martin Gelter, ${ }^{3,4,5}$ Siegfried Sharma, ${ }^{6}$ \\ ${ }^{I}$ The New School, Department of Economics, 6 East $16^{\text {th }}$ Street, $9^{\text {rd }}$ floor 89, New York, NY 10003, USA, \\ Julia.Puaschunder@newschool.edu,T001212229 5700,F001212 229 5724, \\ www.juliampuaschunder.com \\ ${ }^{2}$ Columbia University, Graduate School of Arts and Sciences, Julia.Puaschunder@columbia.edu, \\ http://blogs.cuit.columbia.edu/jmp2265 \\ ${ }^{3}$ Fordham University School of Law, 150 West 62 ${ }^{\text {nd }}$ Street, mgelter@law.fordham.edu \\ ${ }^{4}$ European Corporate Governance Institute \\ ${ }^{5}$ Center on European Union Law \\ ${ }^{6}$ Graz University of Technology, sharma@student.tugraz.at
}

\begin{abstract}
This article tries to grasp our contemporary Zeitgeist to serve as historic landmark how pandemics can influence the individual decision making, the social compound, national order, economic structures and the larger-scale international compound. The ongoing COVID-19 crisis accounts for one of the most unpredicted economic disruptions in the history of humankind. Little would we all have expected how our lives have changed since the outbreak of the pandemic if we consider the deep impact the novel Coronavirus has on all our lives, the legal, economic and political spheres. Featuring national policy strategies to cope with the pandemic grants insights about precautionary and reactionary governance during health crises balancing between medical, economic and social well-being. Concurrent with an already ongoing digitalization trend, the COVID-19 pandemic implies widespread changes for individual decision makers in their adoption of technological assistance but also in giving up decision making to Artificial Intelligence (AI). Economic facets of collective learning processes during the crisis are outlined with a special emphasis on the currently ongoing digital disruption. As a widespread external shock to the world economy and legal order, COVID-19 affects corporate conduct profoundly. The legal implications and societal changes' impetus on corporate conduct will be depicted in order to derive future corporate governance prospects. From an evolutionary dynamics market perspective, a trends prediction sheds light on what kind of firms are likely to fail, which ones may survive and which ones could thrive in the following years and decades to come. International differences in the handling of COVID-19 are highlighted in order to envision future global public healthcare. The recommendations address the importance of well-calibrated goals to cure our contemporary humankind and protect our future common world population.
\end{abstract}

KEYWORDS: Access to healthcare, Artificial Intelligence (AI), Behavioral economics, Behavioral insights, Comparative law, Coronavirus, Corporations, Corporate governance, COVID-19, Crisis, Digitalization, Digidisruption, Economic growth, Healthcare, Herd immunity, History of pandemics, Interest rate, Legal frameworks, Market disruption, Pandemic, Public policy, Technology, Technological changes

\section{COVID-19}

The Coronavirus 2019 (COVID-19) is an infectious disease caused by the severe acute respiratory syndrome coronavirus 2 (SARS-CoV-2). The majority of infected human only develop mild symptoms of fever, cough, fatigue, shortness of breath and loss of smell and taste. Age- and pre-condition dependent, COVID-19 can also lead to acute complications including cytokine storm, multi-organ failure, septic shock and blood clots. While traces of the novel Coronavirus were found as early as the summer 2019 in China and also in Europe in December 2019, the COVID-19 crisis was first officially reported since December 2019 with an outbreak in

\footnotetext{
* The authors thank the TUtheTOP alumni club for hosting an excellent speaker event on 'Digi-Disruption and New Age Renaissance' in May 2020 as well as the additional panelists Dr. Paul Schmelzing and Chair Professor Dr. Alexander Stremitzer and the engaged audience for most helpful share of expertise and interesting discussions that inspired this paper.
} 
Wuhan, China. On January 30, 2020, the World Health Organization (WHO) declared COVID19 a public health emergency of international concern, and by March 11, 2020 a global pandemic. As of June 2020, over 10 million infection cases have been reported in almost 200 countries or all six WHO territories that - so far - caused more than 500,000 deaths with continuously exponentially increasing infection trends and no foreseeable end yet. Currently vaccines and specific treatments are still in testing phases to prevent or cure COVID-19 (United Nations 2020).

The following article addresses COVID-19 from different angles: First, legal changes and governance responses are depicted. Second, technological changes in the wake of the pandemic with special attention to the individual users will be provided. Third, corporate governance changes due to the novel Coronavirus with a potentially lasting impact will be outlined. Fourth, the economic impetus in the wake of COVID-19 with a historic analogy will be given. Lastly, Artificial Intelligence (AI)-led global health governance will be envisioned and the preliminary findings discussed.

\section{COVID-19-induced legal and governance responses}

COVID-19 brought along a wide range of multi-faceted, surprising and intertwined effects. International efforts to combat the pandemic ranged dramatically from totalitarian surveillance to laissez-faire agnosticism of a crisis. Disease control changed legal frameworks for the sake of general security and protection quickly and unpredictably. Temporary criminal and emergency laws placed strict restrictions and measures to ensure lockdowns and social order (Bogdan 2020; Hegheş 2020; Oancea 2020; Şerbănescu 2020). In some jurisdictions thwarting the fight against the disease became a crime, as did non-compliance with hospitalization or quarantine provisions. Some countries even went as far as to criminalize and harshly punish those whose actions seriously affected health and caused infection and/or death of other people (Hegheș 2020). Outcry to protect human rights in times personal monitoring of contagion became prevalent.

Behavioral law and economics advancements grant invaluable insights into softer crowd control. For instance, the previously revealed counterproductive effect of too aspirational goals that may simply turn human off pursuing them may tame our aspiration of a COVID-19 free world in the near future (Leibovitch, Stremitzer \& Versteeg 2019). Realistic governance structure may rather balance the human well-being with economic productivity and social needs of the general populace. Already now, while we are still in the midst of the crisis, a predicament of saving lives or being economically productive and mobile has become apparent. Different strategies have been discussed and pursued by policy makers to combat the pandemic and prepare the general population for a obtaining a general herd immunity. We identified four different strategies that may be summarized as:

(1) Laissez-faire, laissez-vivre features largely unbridled spread of COVID-19, not having any form of lockdown or "social distancing" meaning physical spacing measures, such as in the case of Sweden. This option creates the risk of significant loss of human lives or having a population with lasting deficiencies given potential unknown long-term health effects of a previous COVID-19 infection.

(2) Flattening the curve, which has been pursued by most countries in the world to generate an overall herd immunity within society slowly enough that the medical support remains intact and is not overloaded by too many severe cases at once.

(3) A hard-to-implement age-and-health-status dependent stratified contagion could balance healthcare capacity, pharmaceutical remedies and building herd immunity. Targeted quarantine of those who test positive for COVID-19 with big data tracing apps could be a first step towards a controlled contagion to reach herd immunity (Stremitzer, work in progress). Vulnerable groups of elder and pre-conditioned should thereby be secured and served by herd immune young and healthy. Critical appears the monitoring in terms of privacy. Discrimination 
and stigmatization of protected population groups may occur. A disparate impact of the policies and infringed-upon personal freedoms for the locked-away vulnerable groups is likely.

(4) Time-dependent herd immunity generation could combine flattening-the-curve to have the necessary healthcare built up, and then releasing lockdown measures to obtain herd immunity quickly. This strategy may hard to implement as well as for fiddling with time-sensitive implementation needs highly dependent on accurate understanding of the population health status and infection uncertainties. The risks of such a strategy are - again - unknown long-term consequences of a COVID-19 infection that may impair human lives and the quality of life sustainably.

In addition, public policies must whole-roundedly target at alleviating the socio-economic inequalities and psychological consequences of the novel Coronavirus pandemic (Corlatean 2020; Șchiopu \& Ștefãnescu 2020). For instance, the UNDP recommended five priority areas to address that highlight the vast complexity of the crisis - ranging from the protecting and developing health systems and services to reinforcing social protection; economic stability with special attention to unemployment, small and medium-sized businesses and informal sector workers; making macroeconomic policies work for everyone; promoting peace, good governance and building trust for social cohesion (United Nations 2020).

\section{COVID-19 technology shock}

Individuals constantly adapt to novel, unprecedented situations in trial and error-driven learningby-using (Sharma 2017). Learning-by-using in an industrial setting supports product development with cumulative user experiences shaping innovation (Enos 2002; Komanoff 1976; Miller 1970; Rosenberg 1982; Sharma 2017; von Hippel 1986). Product and service development are especially challenged by complex situations and fast-paced, unpredicted changes in the environment where the service or product is applied. Significant change in utilization behavior, product performance or service level is then triggered depending on the severity of perceived consequences (Sharma 2017). Long-lasting leaps in progress have been observed when the health of users and customers is severely affected or great financial loss experienced (Sharma 2017).

A global pandemic impacts individuals' lives abruptly and unexpectedly. The 2020 COVID pandemic occurred during an already-ongoing digital disruption. Unforeseen lockdowns putting an abrupt halt to physical social interaction triggered a rapid IT adoption in the public and private sectors. Digitalization became the norm for a productive online workforce. Optimal product performance and service provision were - all of a sudden - primarily determined by the peculiar use of the technology in a fast-changing environment. Individuals were more than ever before dependent on instant communication and online connectivity. Previously locally hoarded but scattered knowledge (Rogers 1962; Sharma 2017) is now connected and shared online among users as never before in the digital age. Recognition of the impact of environmental conditions and physical constraints has thereby triggered significant momentum in product development and service performance.

Sharma (2017) points out that even industries with close inter-exchange between user firms and manufacturers - featuring an in-the-field well-established product - may encounter problems that can be of unprecedented notice if external shocks occur. Adjustment may be hindered if firms lack necessary resources with users' ability to adjust being determined by intrinsic and extrinsic motivational factors (Sharma 2017), which can be supported by a guiding environment that picks up novel trends quickly and adapts flexibly.

In technology adoption and user interface research, Sharma (2017) presents evidence for utilization being dominated by problem-recognition as the foundation of solution search. Sharma (2017) finds deviating user-manufacturer opinion to be a significant contributor to job dissatisfaction and directly related to health concerns, stress and physical exhaustion at work. Already now corporations that were run online pre-COVID-19 appear to have an advantageous 
head start when it comes to a necessary tech-savvy workforce that is willing and versed to adopt novel technologies and embark on collective online experiences.

The current pandemic teaches us to particularly pay attention to users' needs and connectivity so that contemporary production process and service provision can be unprecedentedly shaped. In order to understand cumulative mechanisms of novel product userexperience and service performance in a state of crises, we still need a more in-depth theoretical understanding of user theory coupled with applied behavioral research on learning-by-using (Sharma 2017). Subsequent studies of the usability of novel technologies during pandemics but also attention to decision making outsourcing to Artificial Intelligence (AI) in the digital age are required. Ethical cliffs in regards to technology-inequality and connectivity-gaps that were present in hardware, services and software (cf. Bijker et. al. 1992, 2012; MacKenzie and Wajcman 1985; Sharma 2012; Williams 2002) were joined by privacy concerns over time and expanded to online sharing platforms. This needs to be highlighted in order to inform manufacturers, corporations and also governance executives how to alleviate unwanted consequences of the currently ongoing digital disruption.

Even if, one day, we eradicate COVID-19 completely in the digitally-enhanced postCOVID-19 future to come, the positive aspects of a forced digitalization shock, as a pleasant side effect that came along with COVID, may last forever - or at least as long as the next technology innovation builds on it and comes along to disrupt.

\section{COVID-19 and corporate governance}

As Harvard Law School Professor Mark Roe noted already in 2003, "[b]efore a society can produce, it must achieve social peace" (Roe 2003, p. 1). In other words, legal, economic and corporate governance institutions are often not designed to maximize efficiency, but to address a political problem that threatens social cohesion. Only when a society has found lasting stability in the form of a politically-feasible and long-term-sustainable social equilibrium, it can strive to maximize economic productivity and efficiency.

Historical crises - such as the Great Plague of the $14^{\text {th }}$ Century - have often resulted in a reconfiguration of economic structures with unexpected long-term effects (Schmelzing 2019a, b). Similarly, institutional changes responding to the upheaval of the Great Depression and World War II set the course for corporate governance structures that persisted throughout the $20^{\text {th }}$ Century and characterized wealth creation in many countries (Roe 2006, p. 494-510).

It is already apparent that COVID-19 created an external economic shock that has the potential to reconfigure institutions in a way that may determine future generations' well-being. However, COVID-19 is not the only major current concern. The aftermath of the COVID-19 lockdown also triggered social unrest around the world. It is likely that other current social developments will compound its effects, particularly increasing grievance about economic inequality and social justice but also climate change. COVID-19 and the related socio-economic upheaval that we are currently experiencing around the world may have a lasting effect on corporate entities that compete for capital in demanding and highly-constrained crises markets.

Firms will have to become resilient to crises in multiple domains - that of general health and security, but also economic constraints and social upheavals. Firms will have to react to all of these concurrent forces, and the ones adjusting attentively to multiple concerns foresightedly and strategically will thrive. Several prominent firms have become financially troubled because of the spring 2020 lockdown, which may well repeat itself if COVID-19 cannot be eradicated swiftly. They will therefore have to develop structures that allow them to survive health concern legal adjustments, economic interruptions and policy compliance concurrently under contested financial space.

In part, this means that the corporate world will react to rapid, hard-to-predict short-term changes. To stabilize the social order during an emergency period, corporate decision makers 
must flexibly address safety and protection while also be attentive for temporary laws to provide security to their employees.

In the medium and long term, firms will also have to deal with a larger economic fallout and adjust to creative destruction mechanisms that will change corporate patterns (Schumpeter 1934). We may see the development of new corporate governance institutions that are better able to address those issues that are currently causing social disruption. At the same time, public enforcement against corporate crimes may be diminished during periods when emergency measures are in place. In the long run, this may harm corporations if they are eventually punished in a position where they have to pay out extensive damages claims as a result of class action litigation. Corporate compliance that avoids such problems may therefore become particularly necessary.

Corporations that survive the current crisis may consequently become more long-term oriented. Short-term efficiency concerns, including just-in-time logistics but also certain financing practices, will have to shift towards resiliency mode in the years of recovery. Corporations that are not operating merely on an arm's length capital market basis but are integrated into a network, generating by core shareholders, state ownership or lending banking, will likely be in a better position to persevere (Gelter \& Puaschunder, work in progress).

In addition, COVID-19 has resulted in a resurgence of nationalism and protectionism. State-ownership in corporate governance and protectionist have generally been disfavored by advocates of free markets and international trade, as well as corporate governance scholars during the past decades (e.g. Pargendler 2020; Ringe \& Bernitz 2011). This may be surprising in light of the fact that throughout the $20^{\text {th }}$ Century, many countries in fact used protectionist strategist to benefit from infant-industry advantages. Via protectionism they developed local and national champions first in order to generate economic growth and build international competitive advantages for trade in later development stages (Chang 2002). In the future, corporate governance may again become a tool to ensure that national security is not at risk, and that countries have access to key resources, such as raw materials or medicine. We may see, for example, limitations on foreign investment and takeovers, and we may face industrial policy that discourages interconnected supply chains (Gelter \& Puaschunder, work in progress). Firms that adjust to and anticipate governmental protectionism - such as halting immigrant work visas and green card applications in the US - will have competitive advantages because they are able to forestall human resource shortfalls by tapping into already-existing human skills development in their own ranks.

Moreover, the current emphasis on stakeholder orientation in corporate governance focusing on "stakeholder" and "public policy" agendas will likely deepen. The 1990s and 2000s were a period dominated by the idea of shareholder primacy in corporate governance (e.g. Gelter 2018, pp. 330-334). Most corporate governance analysts advanced the shareholder wealth maximization goal, and some even argued that we would see corporate governance world-wide converging toward a shareholder model because of its presumed efficiency (Hansmann \& Kraakman 2001). In recent years, stakeholder theories have made a comeback (e.g. Mayer 2013; Stout 2012). Stakeholder theories are extremely diverse, but generally advance the idea that corporate governance should also attribute the interests of other groups, including workers, and sometimes pursue larger or longer-termed public policy goals. Institutional investors, for instance, increasingly put pressure on corporations to become more environmentally-friendly and attentive to global warming (Condon 2020; Puaschunder 2017a, 2019d, 2020b). While institutional investors are tasked with generating returns for their clients, in part it may be today's public opinion and the political environment. Also novel social media instant communication forces are increasingly pushing firms and institutional investors toward such goals through transparency and online crowd control (Gelter \& Puaschunder work in progress). Regardless of whether such policies are intrinsically beneficial for firms, their shareholders and their employees; firms will therefore likely feel compelled to pursue goals that curry favor in the public eye, including fighting climate change and attempting to relieve social inequality or 
shaping social media communication cultures. As fast-paced and unpredictable all these multiple changes are, those that can adapt quickly, flexibly and vigilantly with compassion for all around will have a head-start competitive edge.

\section{Economic trends around COVID-19}

In the decade prior to COVID, globalization slowed ${ }^{2}$ in international trade, finance and profits abroad. $^{3}$ Global value chains localized ${ }^{4}$ as production re-shored (Puaschunder 2019c, 2020e). Contagion risks emerged in finance, food security and global health safety (Centeno, Creager, Elga, Felton, Katz, Massey \& Shapiro 2013). Nationalism rose in homeland-first and EU-exit sentiments (Profita 2019). The ongoing Coronavirus-crisis exacerbated the trends of slowing globalization putting an abrupt halt to global mobility and migration (Puaschunder 2020e).

Contrary to counter-globalization trends of the past, digitalized data transfer grew globally and exponentially since $2010 .^{5}$ Big data reaping online skyrocketed offering untaxed profits (Puaschunder 2017c). Economic gains occurred in big data hoarding and selling data insights but also penetrating online audiences with targeted advertisement (Puaschunder 2017b). Global regulators fenced ethical boundaries in the world-wide heralding digitalization-disruption (Puaschunder 2017e). ${ }^{6}$

Starting from the beginning of 2020, the novel Coronavirus caused a dramatic downturn for general mobility and international tourism including gastronomy (Puaschunder, 2020e). In April 2020, more than half the world's population resided in countries enforcing lockdowns, which disrupted individual lives, business activities and international mobility. All major world economies suppressing human social interaction spilled over in economic decline around the globe (The Lancet COVID-19 Commission, July 10, 2020). ${ }^{7}$ In the wake of "social distancing" measures, consumption decreased by $32 \%$ in China, $49 \%$ in Germany and $50 \%$ in the US as well as $78 \%$ in Great Britain (BBC, June 30, 2020). The FTSE, Dow Jones Industrial Average and Nikkei plummeted in the first quarter of 2020 drastically. ${ }^{8}$ Unemployment rose in Germany from $3.2 \%$ to $3.9 \%$ thanks to socialist Kurzarbeit protection plans but without those in more marketoriented territories in Great Britain from $3.8 \%$ to $4.8 \%$ and the US from $3.7 \%$ to $10.4 \%$ (IMF, 2020). According to the OECD, $19 \%$ of workers were furloughed in Great Britain, $23 \%$ in Germany and $41 \%$ in France. The IMF estimates a 5-15\% recession chance after the first quarter of 2020 measured by Gross National Product. The world economy shrunk by 3\% in the first quarter and is expected to decline around 5\% throughout 2020. All these measures resemble the Great Depression of the 1930s. The impetus of the novel Coronavirus hits the poor and vulnerable, including low-skilled workers and refugees, unequally hard when it comes to infection rates, seriously-critical symptoms, declined income, and degraded mobility and quality of life (The Lancet COVID-19 Commission, July 10, 2020).

COVID-19 not only implied significant health and security risks, social discrimination and economic costs, but also brought along unanticipated opportunities. Industries that clearly profited economically from the pandemic comprise of hygiene, pharmaceuticals and the medical professions. Economically viewed, COVID-19 is an external shock that accelerated ongoing digitalization trends when considering the rapid technological acceptance for instant communication tools, social engagement and entertainment platforms (Corlatean 2020, Puaschunder 2020e). COVID-19 unleashed the online tech world. Physically distanced, we became digitally closer than ever. On a flat globe, data traffic exploded. ${ }^{9}$ A multi-tasking online workforce ${ }^{10}$ gained global outreach. ${ }^{11}$ Digitalization cut red tape (Puaschunder 2019a). ${ }^{12}$ Health apps targeted at preventing COVID. ${ }^{13}$ Bluetooth-tracking ${ }^{14}$ of medical devices ${ }^{15}$ helped overcome bottlenecks and fraud while protecting privacy. ${ }^{16}$ Telemedicine cured remotely.

International differences in digitalization accentuated during the COVID-19 pandemic. For instance, in China online COVID whistleblowers disappeared. ${ }^{17}$ Strategically-internetcontrolling Asia ${ }^{18}$ and the former Soviet world trumped on mobile crowd control ${ }^{19}$ and social monitoring compliance (Ackermann 2020). ${ }^{20}$ US S\&P 500 leaders $^{21}$ partnered $^{22}$ to pool health 
data; ${ }^{23}$ while freedom-of-speech-fueled information-overload could deadlock relevant communication. $^{24}$ Europe emphasized privacy protection ${ }^{25}$ in envisioning ${ }^{26}$ a $5^{\text {th }}$ freedom of data to harvest network effects of exponentially-growing marginal utility of information (Puaschunder \& Gelter 2019).

In prospective post-COVID economies, hygiene and healthcare will advance (Puaschunder 2019b; Piper 2020). Elder and chronic patients' passing opens market opportunities and fiscal space to evolutionary-dominant, young Corona-survivors. Internet connectivity ${ }^{27}$ and AI-human-compatibility are growing competitive advantages (Puaschunder 2019e, f). Technology-skills and digitalization-affinity hold future strategic edges in a digitalized world (Puaschunder 2019b, g, 2020a). Future global digitalization-healthcare innovations are likely to come from corruption-free AI pioneering countries that tend to have better general medical care (Puaschunder forthcoming b; Rose-Ackerman \& Palifka 2016). Ethical considerations in the age of digitalization include inequality based on interconnectivity and technology access (Corlatean 2020, Puaschunder 2020e).

From the socio-economic standpoint, witnessing suffering and death psychologically

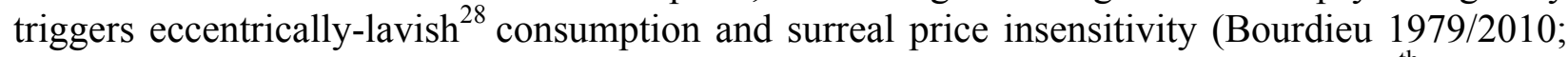
Schmelzing 2019a). Historically, in the aftermath of the Great Plague of the $14^{\text {th }}$ century, extraordinary luxury ${ }^{29}$ consumption economically elevated the Dark Ages into the Renaissance (Keynes 1936; Making Marvels 2019; Piper 2020; Schmelzing 2019a, b; Veblen 1899). The medieval survivors' zest for life and self-determination triggered an enormous potential to build industries enthusiastically focused on present-day gains rather than religious afterlife illusions (Piper 2020; Schmelzing 2019a). Thanks to lowered inflation and social upheaval, luxury became accessible by greater parts of the general population, who enjoyed consumption in the aftermath of death, physical suffering and emotional burdens (Piper 2020; Schmelzing 2019a). Cities flourished, trade picked up stronger than before and intellectually-driven innovations prospered.

From the Renaissance up to Absolutism, society enjoyed luxury in (1) a Gestalt greater than its components; (2) serving the common good fostering social identity in collectively-shared experiences; and (3) ground-breaking innovations demonstrating mastery over nature of the world (Making Marvels 2019; Puaschunder 2020c; Rousseau 1750; Serdari 2016; Tajfel \& Turner 1979).

Future prospective booming industries of the post-COVID-19 era may therefore also feature luxury accessible by all. When striving to reap economic benefits in the post-COVID-19 period, anti-discrimination efforts must protect excellence in luxury that can be an ultimate economic driver trickling down wealth to all parts of society (Keynes 1936; Puaschunder work in progress; Veblen 1899). Luxury in the digital age could become the multiplier that is needed for widespread economic recovery (Keynes 1936). Contrary to naturally-constrained, satiable consumption of ordinary goods with declining marginal utility, data transfer online offers exponentially-increasing marginal utility of information in network effects and non-rivalrous consumption of information alongside exponentially-increasing multi-procal emotional gratification in world-wide virtual collective experiences (Puaschunder 2018a).

In the post-COVID-19 digitalized economies, young tech-entrepreneurs can break the most innovative waves to implement a so-called New Age Renaissance in the Digital Age. The economic future belongs to corporate leaders that boldly envision, design and craft the virtual luxury platforms of tomorrow connecting us for collective information exchange fueled by collective emotions. Corporations that are prepared for online endeavors will have a growing advantage. But the beauty of enjoying lavish network effects and delving into world-wide collective emotional experiences online also bears a responsibility to worship our common virtual luxury temples together wisely, conscientiously and sustainably (Puaschunder 2017d, 2018b, 2020d, forthcoming a). 


\section{International AI-led health governance}

The spread of the new COVID-19 has created challenges for global healthcare with expected long-term effects around the world. The call for global solutions in international healthcare pandemic outbreak monitoring and crisis risk management has generated an unprecedented momentum. Digitalization, AI and big data-derived inferences are supporting human decision making as never before in the history of medicine. In today's healthcare sector and medical profession, AI, algorithms, robotics and big data are used as essential health status tracking devices and healthcare enhancement tools. These new technologies allow monitoring of largescale medical trends and measuring individual risks based on big data-driven estimations (Puaschunder forthcoming b).

The worldwide current state-of-the-art of AI, algorithms, big data-derived inferences and robotics in healthcare varies enormously. Examining medical responses to COVID-19 on a global scale makes international differences in the approaches to combat global pandemics with technological solutions apparent. AI-driven global healthcare primarily exists in global healthcare innovation hubs with economic impetus around the world (Puaschunder, forthcoming b). The parts of the world that feature internet connectivity and high economic productivity (measured in GDP) are likely to lead on AI-driven big data insights for pandemic prevention (Puaschunder, forthcoming b).

When comparing countries worldwide, AI advancement was found to be positively correlated with anti-corruption (Puaschunder forthcoming b). AI thus springs from non-corrupt territories of the world (Puaschunder forthcoming b). Puaschunder (forthcoming b) created a novel anti-corruption artificial healthcare index that highlights those countries in the world that have vital AI growth in a non-corrupt environment, which also breeds excellence in public healthcare (Puaschunder forthcoming b). These non-corrupt AI centers hold comparative advantages to lead on global artificial healthcare solutions against COVID-19 and serve as pandemic crisis and risk management innovators of the future. The countries that score high on AI, anti-corruption and healthcare excellence, are promoted as ultimate innovative global pandemic alleviation leaders (Puaschunder forthcoming b).

\section{Discussion}

Although we are still in the midst of a world-wide pandemic with exponentially rising novel Coronavirus-infections, already now certain is that research can lead to a more informed dialogue about the risks but also the opportunities of COVID-19. Well-informed and consensually-agreedupon recommendations for future-oriented governance of the COVID-19 crisis can help society to grow stronger together as a community. Insights sharing in respectful discourse staged with empathy may guide action that is carried by the masses. All these endeavors will help balance between health, economic well-being, legally-supported social stability and sustainable quality of life of multiple generations living together through a crises that affects us all but differently.

\footnotetext{
${ }^{1} \mathrm{https}: / / \mathrm{www} . w h o . i n t /$ publications/m/item/draft-landscape-of-covid-19-candidate-vaccines

${ }^{2}$ https://www.economist.com/leaders/2019/01/24/the-steam-has-gone-out-of-globalisation

${ }^{3} \mathrm{https}$ ://www.economist.com/finance-and-economics/2019/04/17/is-the-world-economy-still-slowbalising

${ }^{4} \mathrm{https}: / /$ www.economist.com/special-report/2019/07/11/multinational-companies-are-adjusting-to-shorter-supply-chains

${ }^{5} \mathrm{https}: / /$ www.economist.com/leaders/2019/01/24/the-steam-has-gone-out-of-globalisation

${ }^{6}$ TUtheTop COVID-19 Expertenrunde \#2: Wirtschaft in der Krise, March 27, 2020 online at https://zoom.us/webinar/register/WN_V1x7X2V4TI6hjn4zNVxGMA?fbclid=IwAR2JyEtpkUoz0aL9X2sEwhevt8F8JBQjDk3_rTJbeGkE0 aRWYNn172AV4U4\&ct=t(TTTac_COVID-19_ECONOMY)\&mc_cid=2dflcaa7d2\&mc_eid=56675af841

${ }^{7} \mathrm{https}: / /$ unstats.un.org/unsd/ccsa/documents/covid19-report-ccsa.pdf

${ }^{8} \mathrm{https}: / /$ www.bbc.com/news/business-51706225

${ }^{9} \mathrm{https} / / / \mathrm{www} 2 . m o n a s h . e d u /$ impact/articles/big-data/how-novel-coronavirus-covid-19-is-putting-a-strain-on-global-internet-networks/
} 


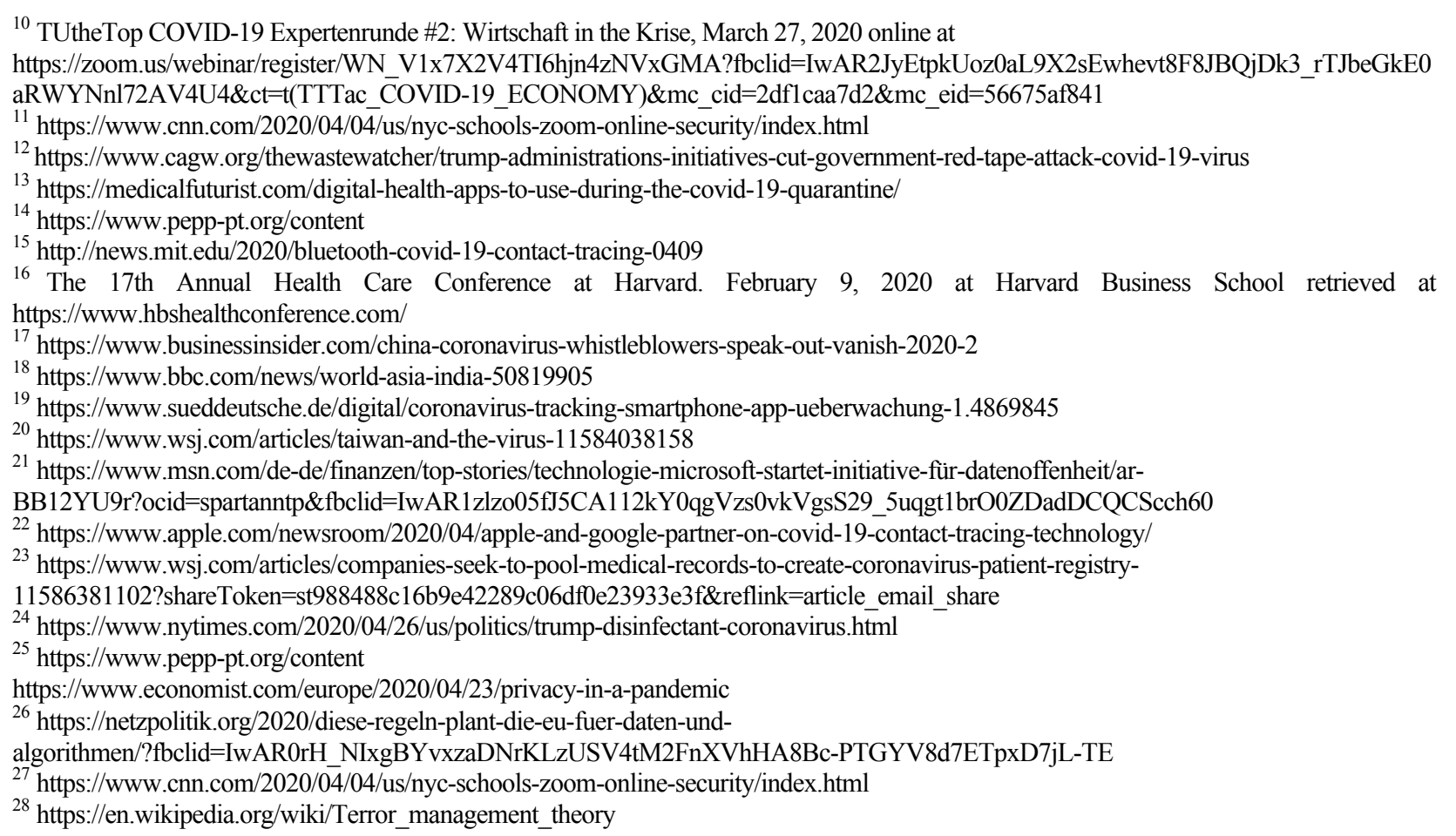

\section{References}

Ackermann, Klaus. 2020. Limiting the market for information as a tool of governance: Evidence from Russia. Melbourne, Australia: Monash University working paper.

Bijker, Wiebe E. et al. 2012. The social construction of technological systems: New directions in the sociology and history of technology. Cambridge: MIT Press.

Bijker, Wiebe E. 1992. Law: Shaping technology/building society: Studies in sociotechnical change.

Bogdan, David. 2020. "The need of introducing one or more temporary criminal laws during the state of emergency (or alert)." Proceedings of the $17^{\text {th }}$ Research Association for Interdisciplinary Studies Conference, June 1-2, 2020.

Bourdieu, Pierre. 1979/2010. Distinction: A social critique of the judgement of taste. London: Routledge.

Centeno, Miguel Angel, M.A., Angela Creager, Adam Elga, Edward Felton, Stanley Katz, William Massey \& Jacob Shapiro. 2013. Global systemic risk: Proposal for a research community. Princeton Institute for International and Regional Studies, Princeton University working paper.

Chang, Ha-Joon. 2002. Kicking away the ladder: Development strategy in historical perspective. London: Anthem.

Condon, Madison. 2020. "Externalities and the common owner." Washington Law Review 95: 1-81.

Corlatean, Titus. 2020. "Risks, discrimination and opportunities for education during the times of COVID19 pandemic." Proceedings of the $17^{\text {th }}$ Research Association for Interdisciplinary Studies Conference, June 1-2, 2020.

Enos, John L. 1962. Petroleum progress and profits: A history of process innovation. Cambridge: MIT Press.

Enos, John L. 2002. Technical progress and profits: Process improvements in petroleum refining. Oxford: Oxford University Press for Oxford Institute for Energy Studies.

Gelter, Martin. 2018. „EU company law harmonization between convergence and varieties of capitalism.” In H. Wells, Research Handbook on the History of Corporation and Company Law. Cheltenham, UK / Northampton, MA, USA: Edward Elgar, 323-352.

Gelter, Martin \& Julia Margarete Puaschunder (work in progress). COVID-19 and comparative corporate governance.

Hansmann, Henry \& Reinier Kraakman. 2001. "The end of history for corporate law." Georgetown Law Journal 89: 439-468. 
Hegheș, Nicoleta-Elena. 2020. "Some considerations regarding the crime of thwarting disease control." Proceedings of the $17^{\text {th }}$ Research Association for Interdisciplinary Studies Conference, June 1-2.

Komanoff, Charles. 1976. Power plant performance: Nuclear and coal capacity factors and economics. Cambridge, MA: Council on Economic Priorities.

Keynes, J. Maynard. 1936. The general theory of employment, interest and money. London: Macmillan.

Leibovitch, Adi, Alexander Stremitzer \& Mila Versteeg. Aspirational rules, 2019. Retrieved at https://micro.econ.kit.edu/downloads/Stremitzer,\%20Leibovitch,\%20Versteeg\%20$\% 20$ Aspirational\%20Rules.pdf.

Making marvels: Science \& splendor at the courts of Europe Exhibition Catalogue. 2019. New York: The Metropolitan Museum of Art.

Miller, Ronald E. 1970. The technical development of modern aviation. New York: Praeger.

Oancea, Clara Maria. 2020. "Amendment of criminal legislation in the context of the current Covid-19 coronavirus pandemic." Proceedings of the $17^{\text {th }}$ Research Association for Interdisciplinary Studies Conference, June 1-2.

Pargendler, Mariana. 2020. "The grip of nationalism on corporate law." Indiana Law Journal 95(2): 533590.

Piper, Nikolaus. 2020. Die Ökonomie des Todes. Süddeutsche Zeitung, April 10, 2020. Retrieved at https://www.sueddeutsche.de/wirtschaft/pest-coronavirus-wirtschaft-1.4873813.

Profita, Sofia. 2019. Slowbalization and its risks. New York: Columbia University working paper.

Puaschunder, Julia Margarete. 2017a. Global responsible intergenerational leadership. Wilmington, DE: Vernon.

Puaschunder, Julia Margarete. 2017b. "Nudging in the digital big data era." European Journal of Economics, Law and Politics 4(4): 18-23.

Puaschunder, Julia Margarete. 2017c. "Nudgital: Critique of a behavioral political economy." Archives of Business Research 5(9): 54-76.

Puaschunder, Julia Margarete. 2017d. "Nudgitize me! A behavioral finance approach to minimize losses and maximize profits from heuristics and biases." International Journal of Management Excellence 10(2): 1241-1256.

Puaschunder, Julia Margarete. 2017e. "The nudging divide in the digital big data era." International Journal of Research in Business, Economics and Management 4(11-12): 49-53.

Puaschunder, Julia Margarete. 2018a. "Dignity and utility of privacy and information sharing in the digital big data age." International Journal of Commerce and Management Research 5(4): 62-70.

Puaschunder, Julia Margarete. 2018b. "Towards a utility theory of privacy and information sharing and the introduction of hyper-hyperbolic discounting in the digital big data age." International Journal of Strategic Information Technology and Applications 10(1): 1-22.

Puaschunder, Julia Margarete. 2019a. "Artificial diplomacy: A guide for public officials to conduct Artificial Intelligence." Journal of Applied Research in the Digital Economy 1: 39-45.

Puaschunder, Julia Margarete. 2019b. Artificial Intelligence, big data, and algorithms in healthcare, Report on behalf of the European Parliament European Liberal Forum in cooperation with The New Austria and Liberal Forum, Retrieved at https://papers.ssrn.com/sol3/papers.cfm?abstract_id=3472885.

Puaschunder, Julia Margarete. 2019c. Artificial Intelligence market disruption. Proceedings of the International RAIS Conference on Social Sciences and Humanities, at Johns Hopkins University, Montgomery County Campus, Rockville, MD, United States, June 10-11, 1-8.

Puaschunder, Julia Margarete. 2019d. Intergenerational equity: Corporate and financial leadership. Cheltenham, UK \& Northampton, MA: Edward Elgar.

Puaschunder, Julia Margarete. 2019e. "On Artificial Intelligence's razor's edge: On the future of democracy and society in the artificial age." Journal of Economics and Business 2(1): 100-119.

Puaschunder, Julia Margarete. 2019f. Stakeholder perspectives on Artificial Intelligence (AI), robotics and big data in healthcare: An empirical study, Retrieved at https://papers.ssrn.com/sol3/papers.cfm?abstract_id=3497261.

Puaschunder, Julia Margarete. $2019 \mathrm{~g}$. The legal and international situation of AI, robotics and big data with attention to healthcare. Reports on behalf of the European Parliament European Liberal Forum in cooperation with The New Austria and Liberal Forum, Retrieved at https://papers.ssrn.com/sol3/papers.cfm?abstract_id=3472885. 
Puaschunder, Julia Margarete. 2020a. Data fiduciary in order to alleviate principal-agent problems in the artificial big data age. 46th Eastern Economic Association Conference, Boston Sheraton, Boston, Massachusetts, United States, February 29.

Puaschunder, Julia Margarete. 2020b. Governance and climate justice: Global South and developing nations. Cham, Switzerland: Palgrave Macmillan Springer Nature.

Puaschunder, Julia Margarete. 2020c. "Making marvels: A reading: Review of making marvels exhibit at The Metropolitan Museum of Art, New York." New York. Luxury: History, Culture, Consumption, $1-16$.

Puaschunder, Julia Margarete. 2020d. On freedom in the artificial age, Retrieved at https://papers.ssrn.com/sol3/papers.cfm?abstract_id=3544348.

Puaschunder, Julia Margarete. 2020e. "Revising growth theory in the Artificial Age: Putty and clay labor." Archives in Business Research 8(3): 65-107.

Puaschunder, Julia Margarete. forthcoming a. "Big data ethics." Journal of Applied Research in the Digital Economy 1: 55-75.

Puaschunder, Julia Margarete. forthcoming b. "The future of Artificial Intelligence in international healthcare: Integrating technology, productivity, anti-corruption and healthcare interaction around the world with three indices." Journal of Applied Research in the Digital Economy.

Puaschunder, Julia Margarete. How to not stop progress: On the law and economics of the discrimination of excellence, work in progress. Retrieved at https://papers.ssrn.com/sol3/papers.cfm?abstract_id=3377646

Puaschunder, Julia Margarete \& Martin Gelter. 2019. On the political economy of the European Union. Proceedings of the 15th International RAIS Conference on Social Sciences and Humanities, at Johns Hopkins University, Montgomery County Campus, Rockville, MD, United States, November 6-7, 2019, 1-9. Retrieved at http://rais.education/wp-content/uploads/2019/11/001JP.pdf

Mayer, Colin. 2013. Firm commitment. Oxford: Oxford University Press.

Ringe, Wolf-Georg \& Ulf Bernitz. 2011. "Company law and economic protectionism: An introduction." In U. Bernitz \& W.-G. Ringe, Company Law and Economic Protectionism. Oxford: Oxford University Press, 1-9.

Roe, Mark J. 2003. Political determinants of corporate governance. Oxford: Oxford University Press.

Roe, Mark J. 2006. "Legal origins, politics, and modern stock markets." Harvard Law Review 120: 460527.

Rogers, Everett M. 1962. Diffusion of Innovations. Glencoe: Free Press.

Rose-Ackerman, Susan and Bonnie J. Palifka. 2016. Corruption and Government: Causes, Consequences, and Reform. Cambridge UK: Cambridge University Press.

Rosenberg, Nathan. 1982. Inside the Black Box: Technology and Economics. Cambridge: Cambridge University Press.

Rousseau, Jean-Jacques. 1750. Discours sur les sciences et les artes. Geneva: Barillot.

Șchiopu, Cristina Gabriela \& Cristinel Ștefănescu. 2020. "Psychiatric consequences of the novel coronavirus pandemic." Proceedings of the $17^{\text {th }}$ Research Association for Interdisciplinary Studies Conference, June 1-2, 2020.

Schmelzing, Paul Ferdinand. 2019a. Eight centuries of global real interest rates, $R-G$, and the 'suprasecular' decline, 1311-2018. London: Bank of England Staff Working Paper No. 845, Retrieved at https://www.bankofengland.co.uk/-/media/boe/files/working-paper/2020/eightcenturies-of-global-real-interest-rates-r-g-and-the-suprasecular-decline-1311-2018.

Schmelzing, Paul Ferdinand. 2019b. Essays on long-term real rate and safe asset trends, 1311-2018. Cambridge, MA: Harvard University Dissertation, Department of History.

Schumpeter, Joseph. 1934. Alois Die Theorie der wirtschaftlichen Entwicklung. Cambridge, MA: Harvard University.

Șerbănescu, Robert. 2020. "The restrictions of fundamental rights during a state of emergency." Proceedings of the $17^{\text {th }}$ Research Association for Interdisciplinary Studies Conference, June 1-2.

Serdari. Thomaï. 2016. "Experiments in suchness: Hiroshi Sugimoto's silk Shiki for Hermès." In J. Armitage \& J. Roberts (Eds.), Critical Luxury Studies: Art, Design, Media. Edinburgh: Edinburgh University Press, 130-150.

Sharma, Siegfried. 2017. "How learning by using is done: Product and process improvement in CNC laser machines." Unpublished Doctoral Dissertation Draft, University of Graz, Austria. 
Sharma, Siegfried. 2012. Gender-Specific Specific Requirements for the Design of Human-Machine Interfaces. Society for Social Studies of Science and European Association for the Study of Science and Technology, Denmark. Oct. 2012.

Stout, Lynn The shareholder value myth. San Francisco: Berrett-Koehler, 2012.

Tajfel, Henri \& John Charles Turner. 1979. "An integrative theory of intergroup conflict." In W. G. Austin \& S. Worchel (Eds.), The Social Psychology of Intergroup Relations. Monterey, CA: Brooks-Cole.

United Nations. 2020. A UN framework for the immediate socio-economic response to COVID-19, 2020. Retrieved at https://www.un.org/sites/un2.un.org/files/un_framework_report_on_covid-19.pdf.

Veblen, Thorstein 1899. The theory of the leisure class. New York: Macmillan. Retrieved at http://moglen.law.columbia.edu/LCS/theoryleisureclass.pdf.

Von Hippel, Eric. 1986. "Lead Users: A Source of Novel Product Concepts." Management Science 32(7): 791-805, July 1986. 